\title{
Origin of successive cambia on stem in three species of Menispermaceae ${ }^{1}$
}

\author{
NEUSA TAMAIO ${ }^{2,5}$, RICARDO CARDOSO VIEIRA ${ }^{3}$ and VERONICA ANGYALOSSY ${ }^{4}$
}

(received: November 6, 2008; accepted: October 14, 2009)

\begin{abstract}
Origin of successive cambia on stem in three species of Menispermaceae). The lianas observed in this study, Abuta convexa (Vell.) Diels, Abuta imene (Mart.) Eichler, and Chondrodendron platiphyllum (A. St.-Hil.) Miers, all have successive cambia in their stems. The terminology applied to stem histology in species with successive cambia is as diverse as the interpretations of the origins of this cambial variant. Therefore, this study specifically investigates the origin of successive cambia through a developmental analysis of the above-mentioned species, including an analysis of the terminology used to describe this cambial variation. For the first time, we have identified several developmental stages giving rise to the origins of successive cambia in this family. First, the pericycle originates in 1-3 layers of conjunctive tissue. After the differentiation of the first ring, the conjunctive tissue undergoes new divisions, developing approximately 10 rows of parenchyma cells. In the middle portion, a layer of sclereids is formed, again subdividing the conjunctive tissue into two parts: internal and external. New cambia originate in the internal part, from which new secondary vascular strands will originate, giving rise to the second successive vascular ring of the stem. The external part remains parenchymatous during the installation of the second ring and will undergo new periclinal division, repeating the entire process. New cambia will originate from the neoformed strands, which will form only rays. In the literature, successive cambia are formed by a meristem called "diffuse lateral meristem.” However, based on the species of Menispermaceae studied in this report, it is demonstrated that the diffuse lateral meristem is the pericycle itself.
\end{abstract}

Key words - Abuta, cambial variant, Chondrodendron, development, liana

RESUMO - (Origem dos câmbios sucessivos em caule de três espécies de Menispermaceae). As lianas observadas neste estudo, Abuta convexa (Vell.) Diels, Abuta imene (Mart.) Eichler e Chondrodendron platiphyllum (A. St.-Hil.) Miers, possuem câmbios sucessivos em seus caules. A terminologia aplicada à histologia de caules de espécies com câmbios sucessivos é tão diversa quanto as interpretações das origens dessa variação cambial. O objetivo deste estudo é investigar a origem dos câmbios sucessivos através de uma análise do desenvolvimento nas espécies supracitadas, incluindo uma análise da terminologia utilizada para descrevê-los. Diversos estágios do desenvolvimento que originam os câmbios sucessivos em Menispermaceae foram constatados. Inicialmente, o periciclo forma de 1 a 3 camadas de tecido conjuntivo. Depois da diferenciação do primeiro anel, o tecido conjuntivo divide-se novamente, desenvolvendo cerca de 10 fileiras de células parenquimáticas. Na porção mediana forma-se um anel de esclereídes, subdividindo o tecido conjuntivo em duas partes. A parte mais interna (tecido conjuntivo interno) forma novos câmbios, que, por sua vez, originam os novos cordões vasculares secundários, formando, assim, o segundo anel vascular sucessivo do caule. A parte mais externa (tecido conjuntivo externo) permanece parenquimática durante a instalação do segundo anel e posteriormente sofrerá novas divisões periclinais, repetindo todo o processo descrito. Entre os cordões neoformados diferenciam-se novos câmbios que produzem somente raios. Conforme a literatura especializada, os câmbios sucessivos são formados por um meristema denominado "meristema lateral difuso". Neste estudo, é demonstrado que nas espécies analisadas o "meristema lateral difuso” é o próprio periciclo.

Palavras-chave - Abuta, Chondrodendron, desenvolvimento, liana, variação cambial

\section{Introduction}

Menispermaceae are mostly vines or lianas, rarely trees, shrubs or herbs (Ortiz et al. 2007). Several

1. Part of the thesis of first author, Programa de Pós-Graduação em Botânica da Universidade de São Paulo.

2. Instituto de Pesquisas Jardim Botânico do Rio de Janeiro, Diretoria de Pesquisa Científica, Rua Pacheco Leão 915, 22460-030 Rio de Janeiro, RJ, Brazil.

3. Universidade Federal do Rio de Janeiro, Departamento de Botânica, Instituto de Biologia, Centro de Ciências da Saúde, Bloco A, Cidade Universitária, Ilha do Fundão, 21941-590 Rio de Janeiro, RJ, Brazil.

4. Universidade de São Paulo, Departamento de Botânica, Instituto de Biociências, 05422-970 São Paulo, SP, Brazil.

5. Corresponding author: neusa@jbrj.gov.br members of this family are known for their medicinal and toxic components. For example, tubocurarine, a neuromuscular blocker and active ingredient in curare, which was used to poison arrows by indigenous people from the South American forests, is derived from the plants of this family (Bisset 1988).

The stems of Menispermaceae lianas are characterized by the presence of successive cambia (Carlquist 1996), being an informative character for phylogenic studies (e.g. Jacques \& Bertolino 2008). This variation is present in 34 dicotyledon families, Welwitschia and in all Gnetum species (Carlquist 1996), and it is characterized by successive rings of axial elements, separated by large xylematic rays and, tangentially, by a conjunctive tissue (e.g. Schenck 1892, 
Solereder 1908, Haberlandt 1914, Pfeiffer 1926, Obaton 1960, Mennega 1982).

The observations regarding the origin of successive cambia in Menispermaceae are controversial. Maheu (1902) proposed four possibilities: cortical parenchyma, endodermis, pericycle and irregular activity of a normal cambium. Jacques \& De Franceschi (2007) believe that other origins are possible, and careful developmental studies of Menispermaceae stems should be carried out to clarify their precise origin. Currently, however, there are no developmental studies of Menispermaceae stems, only some data based on secondary structure, as cited in Carlquist (1996) who states that the origins of successive cambia are found in the most internal cortical layer. This tissue is addressed by this author as the "meristem." It is precisely this range of possibilities that has motivated this report which undertakes a developmental study of the lianas Abuta convexa (Vell.) Diels, Abuta imene (Mart.) Eichler and Chondrodendron platiphyllum (A. St.-Hil.) Miers. It aims to identify the origin of successive cambia in a more accurate manner than previously presented in the literature.

\section{Material and methods}

The specimens were collected from the arboretum and the outskirts of the Instituto de Pesquisas Jardim Botânico do Rio de Janeiro (table 1). The plants from the arboretum are cultivated, whereas those from the outskirts are wild.

The Jardim Botânico arboretum is located in Rio de Janeiro (22 58 ' $14^{\prime \prime} \mathrm{S}$ and $43^{\circ} 13^{\prime} 18^{\prime \prime}$ W). According to Embrapa (1992), the climate type of the Jardim Botânico is Af (rainy, humid and tropical); information obtained by the Koeppen classification indicates that thermal averages range around $29^{\circ} \mathrm{C}$ in summer and $22^{\circ} \mathrm{C}$ in winter. The annual average precipitation is approximately $1.075 \mathrm{~mm}$, with abundant rain in summer and almost none in winter. December, January and February are the rainiest months. The outskirts of

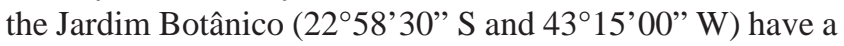
cover that is typical of Dense Ombrophile Forest (Velloso et al. 1991). The climatological data are similar to the abovementioned arboretum. The material was identified by Dr. João Marcelo Alvarenga Braga of the Instituto de Pesquisas Jardim Botânico do Rio de Janeiro, and woody portions were added to the Institute's wood collection - RBW (table 1).

The stem samples collected were separated into two groups, one with caulinar apexes and young portions, i.e., only with the first vascular ring formed, and the other with two or more vascular rings. The first group was fixed with $2.5 \%$ glutaraldehyde in $0.1 \mathrm{M} \mathrm{pH} 7.2$ phosphate buffer solution (Gabriel 1982). The second group was fixed with FAA (acetic acid, formaldehyde and 70\% ethanol) (Berlyn \& Miksche 1976). The material from both groups was dehydrated in ethylic series and processed according the usual methods for Hydroxyethylmethacrylate (Gerrits \& Smid 1983) in order to obtain 3-7 $\mu \mathrm{m}$ thick transversal sections through rotating microtome. Later, the sections were stained with $0.05 \%$ toluidine blue (O’Brien \& McCully 1981).

\section{Results}

Origin of conjunctive tissue - As shown in figure 1, successive cambia in the stem of the species investigated can be observed macroscopically.

At the beginning of the secondary growth (figure 2), the stem presents an epidermis with tectorial trichomes and a cortex with 4-5 thin cell layers. The endodermis can be detected by the presence of cells with starch grains only in places next to interfascicular zones (figure $3)$. In this study, these zones are called grooves. At this stage, the multiseriate pericycle is still undergoing differentiation (figure 2). After differentiation, it is characterized externally by fiber layers and internally by parenchymal cells surrounding the phloem tissue (figures 2 and 4). A large amount of sclerenchyma in abaxial position relative to the protoxylem is observed (figure 2).

It should be noted that some pericyclic cells of the outermost layer, i.e., adjacent to the endodermis, do not lignify (figures 4 and 5). Concomitant with secondary

Table 1. Studied species with collector number and location. JBRJ: Instituto de Pesquisas Jardim Botânico do Rio de Janeiro.

\begin{tabular}{lll}
\hline Species & Collector number & Locality (JBRJ) \\
\hline Abuta convexa (Vell.) Diels & N. Tamaio 29 & outskirts \\
& N. Tamaio 30 & outskirts \\
Abuta imene (Mart.) Eichler & N. Tamaio 97 & arboretum \\
Chondrodendron platiphyllum (A. St.-Hil.) Miers & N. Tamaio 43 & outskirts \\
& N. Tamaio 44 & arboretum \\
\hline
\end{tabular}




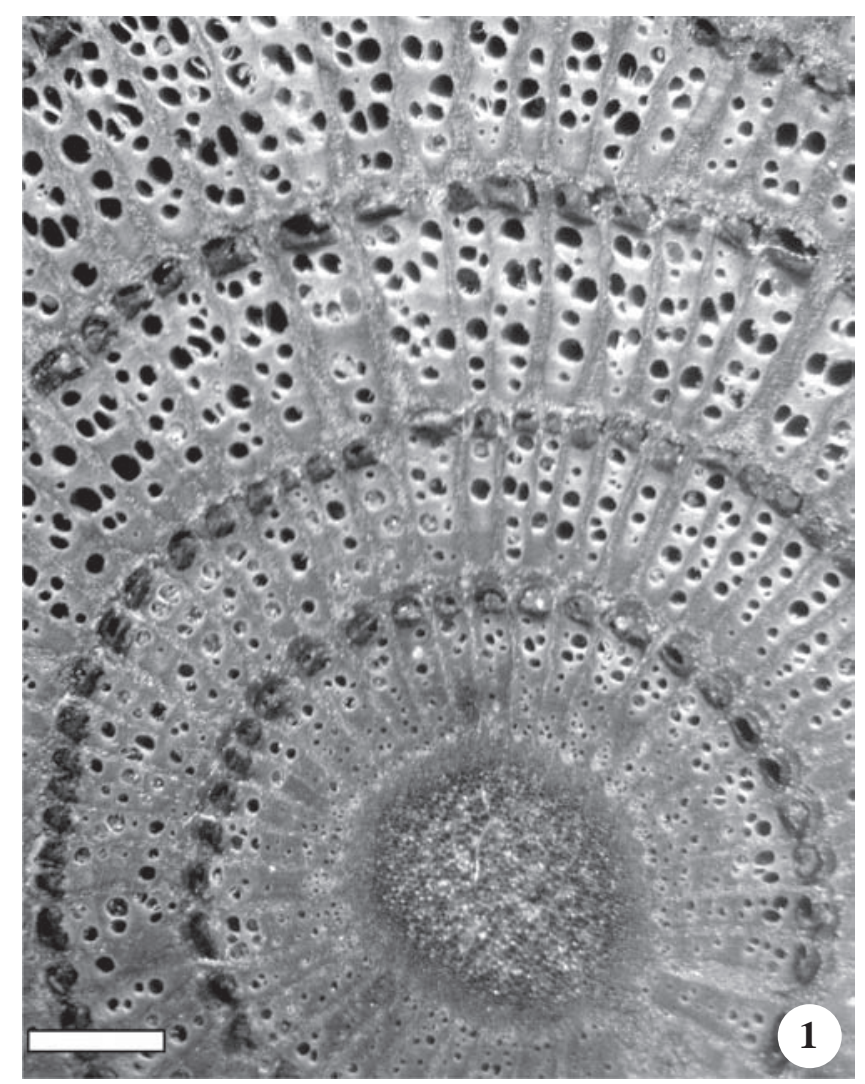

Figure 1. Abuta convexa. Macroscopic observation of the stem with successive cambia. Transverse section. (Bar = $1 \mathrm{~mm})$.

growth establishment, divisions in these cells take place (figures 6 to 9), forming a two-to-three-cell wide layer (figure 10). In this study, this neoformed tissue is called conjunctive tissue.

Cambia of procambial origin form the axial tissues, whereas cambia of pericyclic origin only form vascular rays (figure 11). The presence of a medullary ray constituted of parenchyma cells longer than medullary cells is observed (figure 12). The medullary ray connects to the xylem ray, and the latter can be detected by its cells, which are narrower than its medullary counterparts (figure 12). Figure 13 shows a stem with a differentiated first vascular ring, giving evidence of a configuration in which the axial elements, which are the dominant vascular segments in this study, remain separated from each other by broad rays. Later, new cambia will be centripetally added, thus forming the successive rings, as described below.

Origin of new cambia - After differentiation of the first vascular ring (figure 13), the conjunctive tissue, which undergoes differentiation at the beginning of cambial establishment (figure 10), will now undergo divisions (figure 14) throughout the stem's circumference. These dividing cells are internal to the endodermis, reinforcing the pericyclic origin of the conjunctive tissue (figure 14). Initially, the conjunctive tissue is formed by approximately ten cell layers with a rectangular format arranged in files, and each file originates from one single cell, being yet meristematic as observed in figures 15 and 16. Approximately in the middle of these layers, a ring of cells differentiates into sclereids, subdividing the conjunctive tissue into two parts. The cambia, which will form the second vascular ring, will originate from the innermost part called the internal conjunctive tissue. On the other hand, the outermost part of the conjunctive tissue, called the external conjunctive tissue, will remain parenchymatic during the establishment of the second vascular ring (figure 15).

The establishment of the cambia is asynchronous, fragmenting into short meristematic bands, which initiate at the groove zones and form the first vascular segment of the second ring (figures 15 and 16). Cambia of neoformed segments only give rise to the axial elements of the phloem and xylem (figure 17), repeating the first vascular ring pattern (figure 13). New cambial bands, which are adjacent to the first vascular segment, only originate from the radial parenchyma and will be formed next (figures 16, 18 and 20). It should be noted that the phloem rays, both at the first and subsequent rings, are short and only composed of 2 or 3 cells, as shown in figures 20 and 22. While the second ring is being established, the external conjunctive tissue loses its initial pile configuration and becomes quiescent, taking up an organization similar to the cortex (figures 18, 19 and 21). After this latency period, and after a considerable cambial activity, the external conjunctive tissue resumes its meristematic activity, repeating the whole successive ring formation process, as previously described. These successive steps can be observed in figures 22 to 24 . It is stressed that when there is installation of the second ring, the first ring is already totally differentiated, however, when the installation of the third ring begins, the second ring is still installing.

Successive rings have a similar anatomical pattern and are separated by residual internal conjunctive tissue. However, in relation to the sclerenchyma, there are differences in the separation of the first ring from the others. The sclerenchyma is represented by fibrous pericycle between the first and the second ring and by a ring of sclereids of conjunctive tissue origin between the remaining ones (figure 22). In figure 24, the concentric arrangement of the successive vascular rings can be observed. 

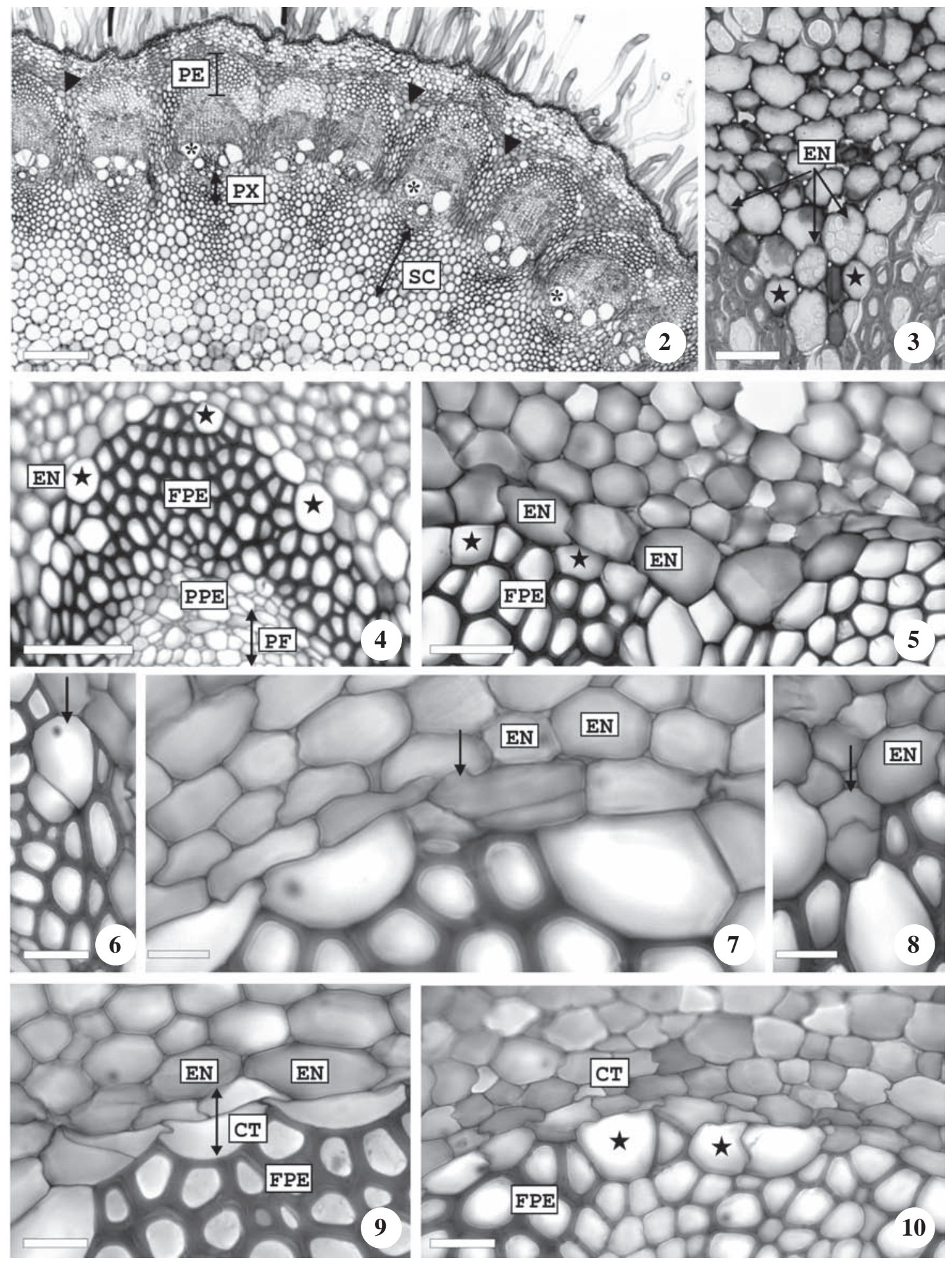

Figures 2-10. Abuta convexa. Transverse sections showing the installation of the conjunctive tissue. 2. Note pericycle in differentiation. 3. Detail of the groove where the endodermis with starch grains. 4. Pericycle, externally differentiated by fibers and internally by parenchyma cells. 5. Cells of the fibrous pericycle that remain parenchymatous, adjacent to the endodermis. 6-10. Divisions in parenchyma cell of the fibrous pericycle. (CT = conjunctive tissue; $\mathrm{EN}$ = endodermis; FPE = fibrous pericycle; $\mathrm{PE}=$ pericycle in differentiation; $\mathrm{PF}$ = primary phloem; $\mathrm{PPE}=$ parenchymatous pericyle; $\mathrm{PX}$ = protoxylem; $\mathrm{SC}$ = sclerenchyma; arrowhead $=$ region of the grooves where the endodermis presents amyloplasts; $\star=$ parenchyma cell of the fibrous pericycle; $*$ = first vessel formed by the vascular cambium; arrow = parenchyma cell of the fibrous pericycle in division). Bar $=130 \mu \mathrm{m}$ (2); $40 \mu \mathrm{m}$ (3, 4, 6); $30 \mu \mathrm{m}$ (5, 8, 9); $20 \mu \mathrm{m}$ (7); $35 \mu \mathrm{m}$ (10). 

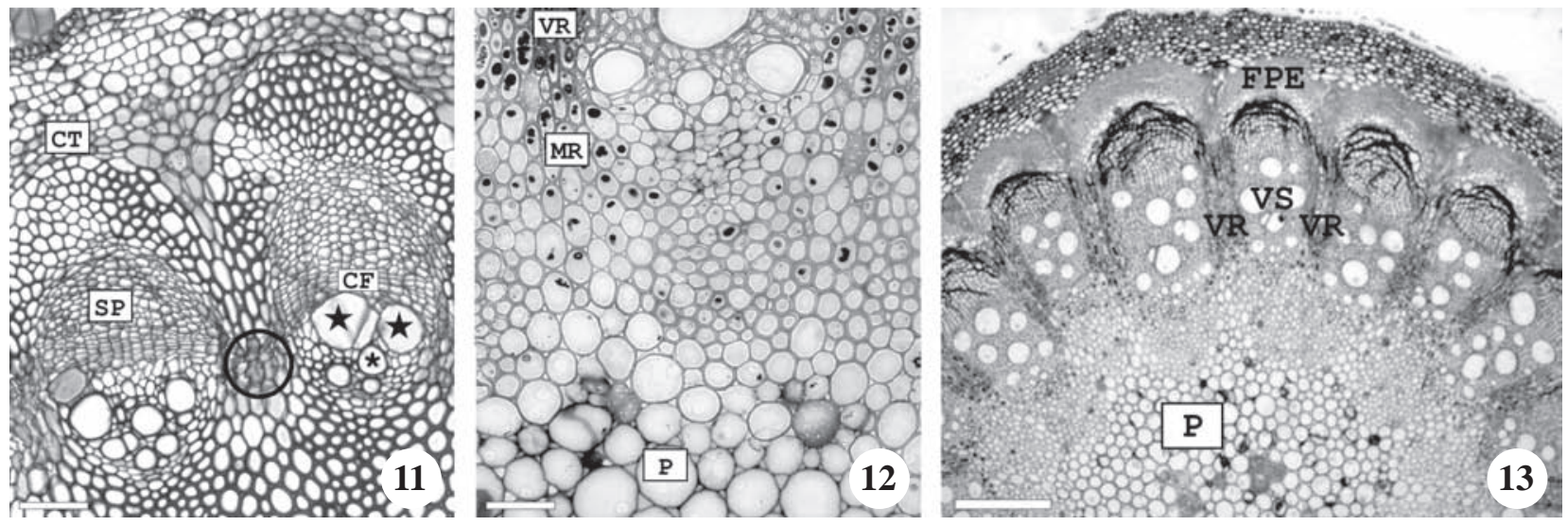

Figures 11-13. Transverse sections showing the installation of the secondary growth. 11. Abuta convexa. Note active fascicular cambium and installed interfascicular cambium. 12. Chondrodendron platiphyllum. Note vascular ray and medullary ray. 13. Abuta convexa. Final configuration of the first formed vascular ring: groups of axial cells (vascular strands) separated by broad vascular rays. Note fibrous pericycle. $(\mathrm{CF}=$ active fascicular cambium; $\mathrm{CT}=$ conjunctive tissue; $\mathrm{P}=$ pith; $\mathrm{MR}=$ medullary ray; FPE = fibrous pericycle; $\mathrm{SP}=$ secondary phloem; $\mathrm{VR}=$ vascular ray; $\mathrm{VS}=$ vascular strands; $\star \star=$ elements of the secondary xylem vessels in differentiation; * = metaxylem; circle = installed interfascicular cambium). Bar = $90 \mu \mathrm{m}(11) ; 70 \mu \mathrm{m}(12)$; $150 \mu \mathrm{m}(13)$.
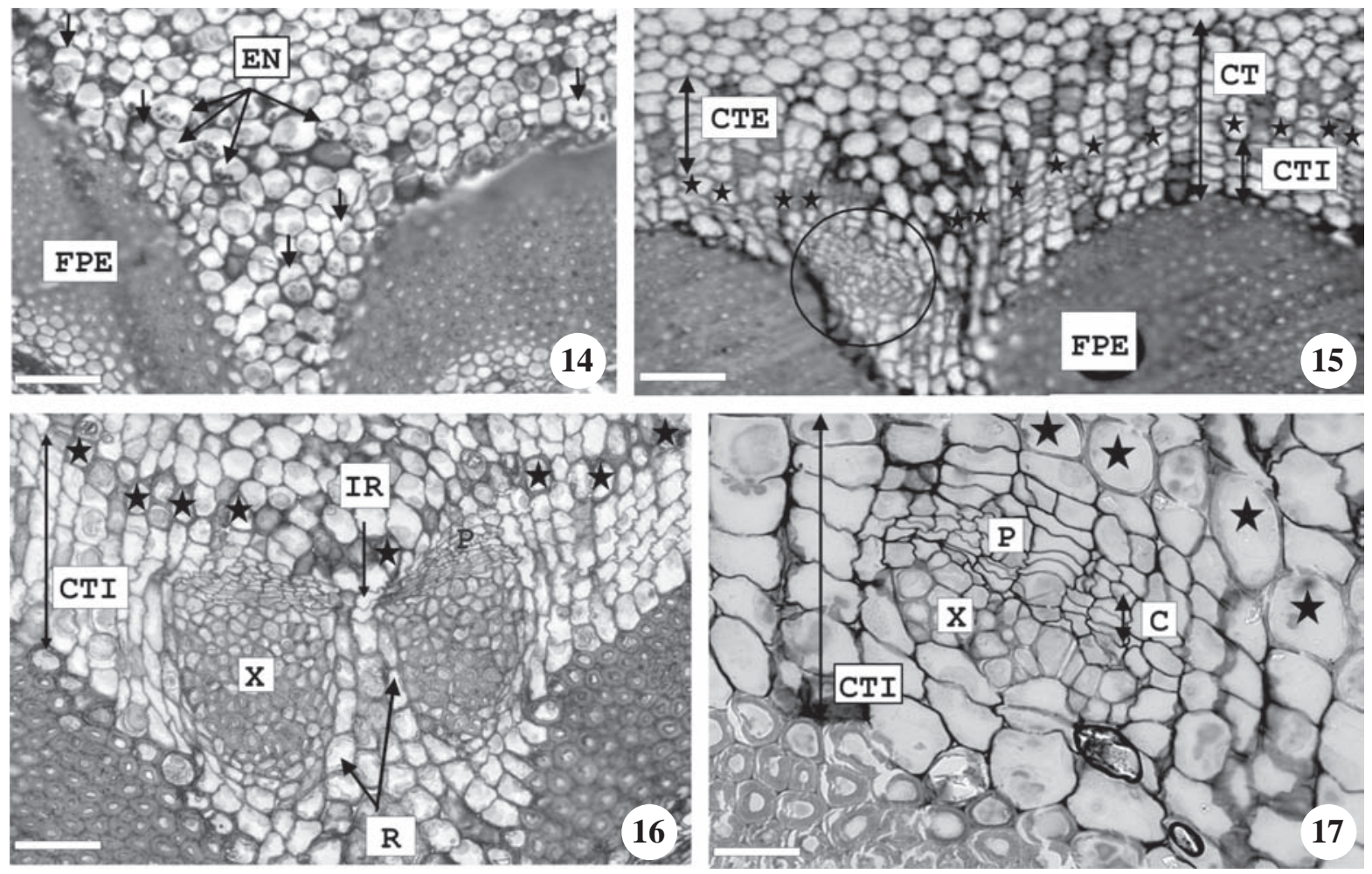

Figures 14-17. Abuta imene. Transverse sections showing the installation of the second vascular ring. 14. Divisions in the cells of the conjunctive tissue. 15. Conjunctive tissue constituted by stack of cells; the ring of pericyclic sclereids subdivides the conjunctive tissue in two parts: external conjunctive tissue and internal conjunctive tissue; the new vascular strand installs, initially, in the grooves area. 16. Two vascular strands with phloem and xylem in installation. Note the cambium installed between the two vascular strands, constituted by initial radial. Note the cells of the conjunctive tissue forming stack of cells. 17. Neoformed vascular strand. Note the cambium producing phloem and xylem. (C = cambium; $\mathrm{CT}=$ conjunctive tissue; $\mathrm{CTE}$ = external conjunctive tissue; $\mathrm{CTI}$ = internal conjunctive tissue; $\mathrm{EN}$ = endodermis; IR = initial radial; FPE = fibrous pericycle; $\mathrm{P}$ = secondary phloem; $\mathrm{R}$ = ray cells; $\mathrm{X}=$ secondary xylem; arrows = divisions in cells of the conjunctive tissue; $\star$ = ring of sclereids; circle = new vascular strands). Bar = $45 \mu \mathrm{m}$ (14); $60 \mu \mathrm{m}$ (15); $65 \mu \mathrm{m}$ (16); $20 \mu \mathrm{m}$ (17). 

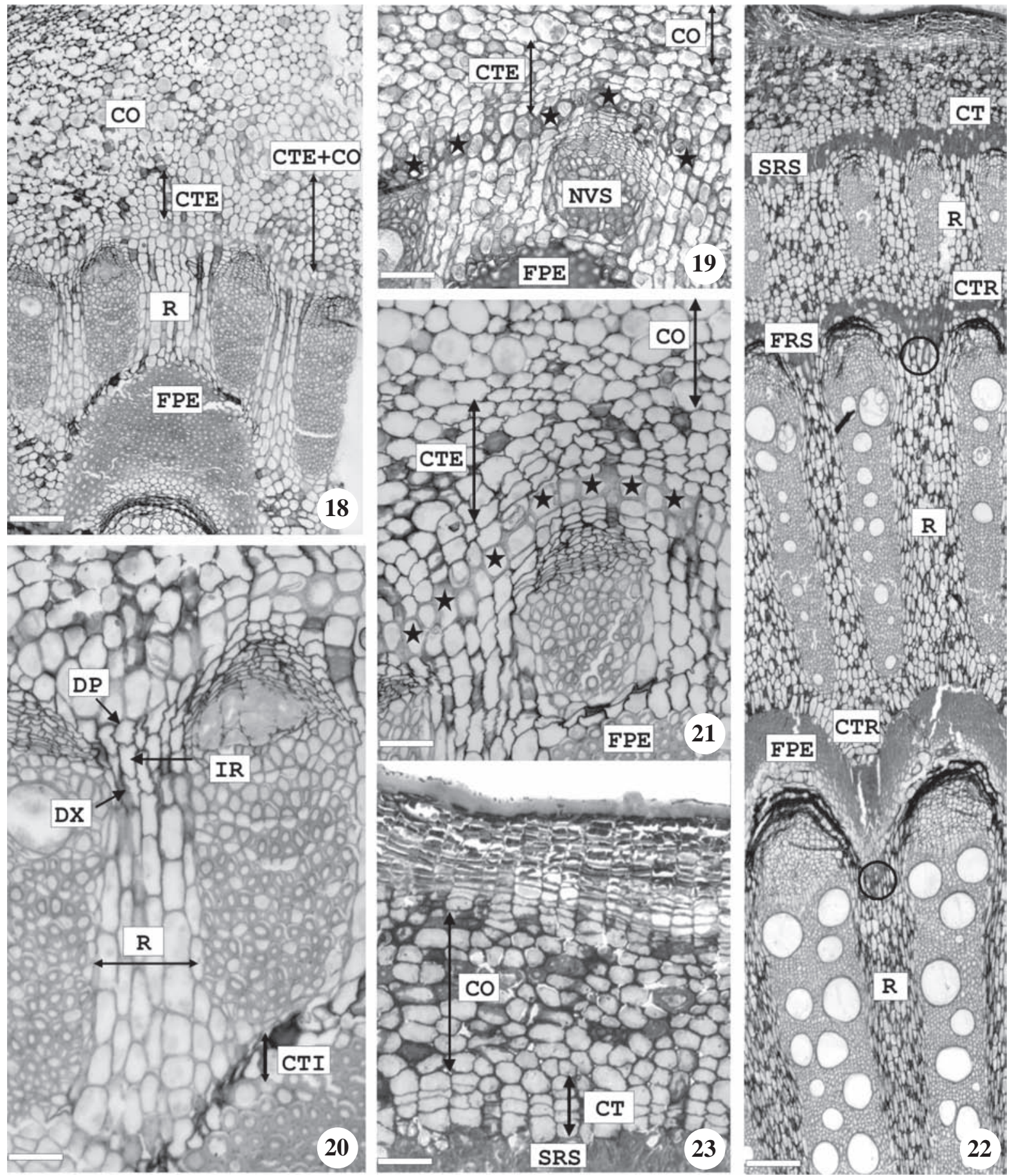

Figures 18-23. Transverse sections showing growth of successive cambia. 18-21. Abuta imene. 22-23. Chondrodendron platiphyllum. 18. Conjunctive tissue forming piles. Note that after the complete differentiation of the external conjunctive tissue, its cells are very similar to the cortical cells (region at the right side). 19. Cell divisions in the external conjunctive tissue. New vascular strand. Ring of sclereids. 20. Note the initial radial; the cell derived from the phloem and the one derived from the xylem. 21. Divisions in the external conjunctive tissue. Ring of sclereids. 22. The vascular rings are separated by residual conjunctive tissue. Note phloem ray constituted by few cells. 23. Detail of the previous image. The conjunctive tissue resumes its meristematic activity and will form the third successive vascular ring. ( $\mathrm{CO}=$ cortex; $\mathrm{CT}=$ conjunctive tissue; CTE = external conjunctive tissue; $\mathrm{CTI}=$ internal conjunctive tissue; $\mathrm{CTR}=$ residual conjunctive tissue; $\mathrm{DP}=$ derived from the phloem; DX = derived from the xylem; FRS = first ring of sclereids; FPE = fibrous pericycle; IR = initial radial; NVS = new vascular strand; $\mathrm{R}=$ vascular ray; SRS = second ring of sclereids; $\star$ = ring of sclereids; circle $=$ phloem ray). Bar $=120 \mu \mathrm{m}$ (18); $80 \mu \mathrm{m}$ (19); $60 \mu \mathrm{m}$ (20), $70 \mu \mathrm{m}$ (21); $100 \mu \mathrm{m}$ (22); $50 \mu \mathrm{m}$ (23). 


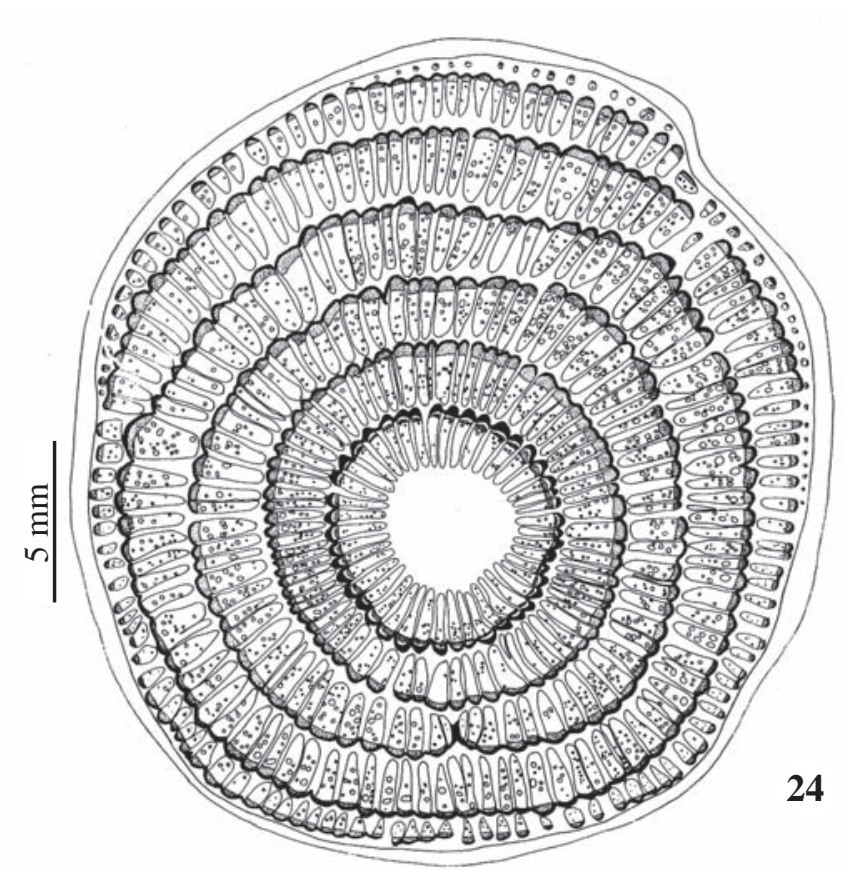

Figure 24. Schematic drawing of the stem of Abuta convexa, in transverse section, with several successive vascular rings in concentric disposition.

\section{Discussion}

The stem and wood anatomy of Menispermaceae has been studied by different investigators, with the most important contributions being those of Schenck (1892), Mennega (1982), Carlquist (1996) and Jacques \& De Franceschi (2007). These studies have shown that most of the genera form successive cambia.

However, interpretations regarding the origin of successive cambia are inconclusive, and, furthermore, they are not directly representative of any research ever performed on the Menispermaceae family, with the exception of some data based on secondary structure (e.g. Carlquist 1996, Rajput \& Rao 2003). In fact, there are more detailed studies on the following families: Amaranthaceae, Aizoaceae,Chenopodiaceae,Leguminosae, Nyctaginaceae, Convolvulaceae and Phytollacaceae. In these families, the pattern of secondary thickening is only superficially similar to Menispermaceae, and the literature has proposed different origins for successive cambia: cortex (Pfeiffer 1926, Chalk \& Chattaway 1937, Balfour 1965, Mikesell \& Popham 1976, Mikesell 1979, Carlquist 1999, 2007, Rajput \& Rao 2008), pericycle (Haberlandt 1914, Pfeiffer 1926, Chalk \& Chattaway 1937, Joshi 1937, Mikesell \& Popham 1976, Mikesell 1979, Fahn \& Zimmermann 1982), phloem (Metcalfe \& Chalk 1950, Wheat 1977, Nair \& Ram 1990).
Generally speaking, when authors do not recognize the presence of a pericycle in the stem, we find a tendency to attribute the origin of successive cambia to the cortex. We agree with Menezes et al. (2005) in the sense that tissue continues through the roots, stem and leaves and, as such, the pericycle remains alive in the stem as a vascular tissue generator during the plant's life cycle. Thus, we believe that the presence of a pericycle is the key to understanding the origin of successive cambia. In fact, the results of this study corroborate previous reports of the presence of endodermis and pericycle in Menispermaceae stems. The first acknowledgements are attributed to Blottière (1886) and Maheu (1902). Blottière (1886), in fact, recognizes that there is a parenchymatic portion of pericycle, as well as another one, which is more external and lignified, just as demonstrated by the species we have analyzed. We also found the presence of endodermic cells containing starch grains, even if only in zones adjacent to the vascular rays, which support the pericycle as the cell layer that forms conjunctive tissue. Importantly, during this activity, the endodermis is distally removed, thus discarding either endodermis or other cortex zone as origins of successive cambia. Specifically, the conjunctive tissue, simultaneously formed with the cambial establishment still at the first ring, will become quiescent and resume meristematic activity only after complete differentiation of the second ring, i.e., after the establishment of the secondary growth differentiates into conjunctive tissue. To our knowledge, these phenomena have not been previously reported.

Initially, the conjunctive tissue is formed by radial files of cells that show activity of a meristem (pericyclic). Approximately in the middle of these layers, a ring of cells differentiates into sclereids, subdividing the conjunctive tissue into two parts - internal conjunctive tissue and external conjunctive tissue. Cells of the internal conjunctive tissue differentiate into new cambia, while the external conjunctive tissue is the site for new cambium in the future. The action of each new cambium normally produces tissue in fascicular areas separated by rays. Therefore, when we use the term "successive cambia," we include both phenomena just described, not just the formation of supernumerary cambia. As such, we must ask whether both conjunctive tissue and new cambia are produced by the same meristem.

To answer this question, it is necessary to cite works that have investigated the origin of successive cambia in Menispermaceae: Carlquist (1996) who examined the liana Hypserpa decumbens (Benth.) Diels and Rajput \& Rao (2003) who examined the shrub Cocculus hirsutus 
(L.) Diels. However, it should first be noted that the descriptions of successive cambia in these works were based on secondary structure. This would imply that these reports were based on data collected after the establishment of secondary growth differentiation and, thus, it is possible that an insufficient number of stages of stem differentiation were examined.

In their brief accounts, these researchers verified the origin of a lateral meristem from the most internal cortical layer, close to a sclerenchyma band. Regarding the nature of this band, a discussion of the different positions can be found in Rajput \& Rao (2003), as follows: "In Cocculus hirsutus, the second ring of cambium develops from the cortical parenchyma next to the pericyclic fibers," while in the results, the authors go on to state that "later on it ceases to divide and a complete new ring of cambium develops from the divisions of cortical parenchyma cells located outside the perivascular fiber bands." Carlquist (1996), however, does not address the nature of this band, commenting only that it may have protophloem fibers: "...the sclerenchyma associated with the first cambium may contain protophloem fibers, but the sclerenchyma associated with subsequent cambia lacks any phloem fibers." Nonetheless, when approaching the origin of successive cambia in general, Carlquist (2007) accepts the involvement of the pericycle in the formation of successive cambia, but only in the root. This indicates that he does not accept the presence of the pericycle in the stem of dicotyledons. Since neither author acknowledges the presence of the pericycle in the stem, we find only the term "meristem" in their writings as the tissue responsible for this cambial variant (Carlquist 1996, Rajput \& Rao 2003).

Carlquist comments that the first cells layers formed by the "meristem" are meristematic conjunctive tissue while Rajput \& Rao (2003) does not use the term "conjunctive tissue", assigning it only as "wide band of meristematic cells". Regardless of the term used, both consider that the layers recently formed are yet meristematic, in other words, immature, such as in the work presented here.

Carlquist (1996) states that the new cambia are formed in the conjunctive tissue while Rajput \& Rao (2003) states that every new cambium first produces conjunctive tissue followed by lignified xylem derivatives. We agree only with Carlquist (1996), because in the present work we observe that the new cambia form only xylem and phloem.

We concluded that the conjunctive tissue and new cambia are formed by the same meristem, which answers the question raised above.
Meanwhile, the shifting terminology used to describe this cambial variant and its origin has caused some scientific confusion to arise. For example, most genera in the Centrospermae family having a lateral meristem are described variously by different authors: primary thickening meristem - PTM (Stevenson \& Popham 1973, Mikesell \& Popham 1976, Mikessel 1979, Yarrow \& Popham 1981, Carlquist 1988), diffuse lateral meristem (Carlquist 1999), confined meristem (Carlquist 2001), lateral meristem (Carlquist 2004) and master cambium (Carlquist 2007).

The term PTM, as it applies to dicotyledons, is criticized by DeMason (1983) who indicates that PTM is an inappropriate term for Centrospermae, citing, among other considerations, that the PTM involves the primary meristem, whereas the "cambium" in the Centrospermae involves the secondary meristem. We do agree with DeMason (1983) that the PTM, along with apical meristems, have the function of forming the plant's primary body (Rudall 1991). Thus, it is erroneous to state that this meristem produces secondary tissues. However, we are more in agreement with Menezes et al. (2005) who have introduced a new interpretive proposal for the primary thickening meristem, now describing the PTM as the pericycle in a meristematic phase, together with the endodermis and its derivatives (or only the pericycle). Since we have confirmed by the species analyzed in this study that successive cambia do originate from the pericycle, we can conclude that meristematic conjunctive tissue of Menispermaceae and the PTM are the same structure which with different names, thus bringing more clarity to these distinctions in the literature.

Finally, it should also be noted that Carlquist (2007) most recently proposed assigning still another new term for that tissue which produces successive cambia. Specifically, he introduced the term "master cambium" as a replacement for his own term, "lateral meristem," as the author considered it vague during a review study, which included several families and which was based on previously published data. However, although Carlquist (2007) claims that the master cambium is lacking in Gnetum africanum Welw. and the large tropical lianas (Bauhinia, Menispermaceae), he later states (p. 307) that new master cambia do form de novo in cortical cells. Since the findings in this study confirm the pericycle as the meristem responsible for successive cambia, Carlquist's apparent inconsistency raises another question: whether the "master cambium" is present in other families with successive cambia and, if so, whether the "master cambium" would be the pericycle itself, as we have described it in this study. To address this 
question, the term "master cambium" should, in general, be carefully analyzed by large studies, as Carlquist himself (2007, p.303) only hesitantly introduces this term. Also, because this is a new paradigm, it must be investigated and debated by more researchers. To accomplish this, a higher number of taxa and other families must be accurately analyzed.

Acknowledgements - We thank the staff at Laboratório de Botânica Estrutural of the Instituto de Pesquisas Jardim Botânico do Rio de Janeiro for technical support, Dr. João Marcelo Alvarenga Braga for taxonomic identification and providing information about the species, Dra. Nanuza Luiza de Menezes for her suggestions, Daniela Canticas for helping in the English language composition, David Martin for reviewing the translation, Paulo Ormindo for the drawings for figure 24 and Programa Mata Atlântica (Petrobras) for funding.

\section{References}

BALFOUR, E. 1965. Anomalous secondary thickening in Chenopodiaceae, Nyctaginaceae, and Amaranthaceae. Phytomorphology 15:111-122.

BERLYN, G.P. \& MIKSCHE, J.P. 1976. Botanical microtechnique and cytochemistry. Iowa State University Press, Ames.

BISSET, N.G. 1988. Curare-botany, chemistry, and pharmacology. Acta Amazonica 18:255-290.

BLOTTIÈRE, R. 1886. Étude anatomique de la famille des Ménispermées. Thèse, École Supérieure de Pharmacie, Paris.

CARLQUIST, S. 1988. Comparative wood anatomy. Systematic, ecological and evolutionary aspects of dicotyledon wood. Springer-Verlag, New York.

CARLQUIST, S. 1996. Wood and stem anatomy of Menispermaceae. Aliso 14:155-170.

CARLQUIST, S. 1999. Wood and stem anatomy of Stegnosperma (Caryophyllales); phylogenetic relationships; nature of lateral meristems and successive cambial activity. IAWA Journal 20:149-164.

CARLQUIST, S. 2001. Comparative wood anatomy. Systematic, ecological and evolutionary aspects of dicotyledon wood. $2^{\text {nd }}$ ed., Springer Verlag, Berlin.

CARLQUIST, S. 2004. Lateral meristems, successive cambia and their products: a reinterpretation base on roots and stems of Nyctaginaceae. Botanical Journal of Linnean Society 146:129-143.

CARLQUIST, S. 2007. Successive cambia revisited: ontogeny, histology, diversity, and functional significance. Journal of the Torrey Botanical Society 134:301-302.

CHALK, L. \& CHATTAWAY, M.M. 1937. Identification of woods with included phloem. Tropical Woods 50:1-31.

DEMASON, D.A. 1983. The primary thickening meristem: definition and function in monocotyledons. American Journal of Botany 70:1195-1204.
EMBRAPA - Empresa Brasileira de Pesquisa Agropecuária. 1992. Identificação de limitações pedológicas e ambientais causadoras da degradação de áreas do Jardim Botânico do Rio de Janeiro. Embrapa - SNLCS, Rio de Janeiro, Série Estudos e Contribuições no 10.

FAHN, A. \& ZIMMERMANN, M.H. 1982. Development of the successive cambia in Atriplex halimus (Chenopodiaceae). Botanical Gazette 143:353-357.

GABRIEL, B.L. 1982. Biological electron microscopy. Van Nostrand Reinhold, New York.

GERRITS, P.O. \& SMID, L. 1983. A new, less toxic polymerization system for the embebdding of soft tissues in glycol methacrylate and subsequent preparing of serial sections. Journal of Microscopy 132:81-85.

HABERLANDT, G.F.J. 1914. Physiological plant anatomy. Macmillan Co, London.

JACQUES, F.M.B. \& BERTOLINO, P. 2008. Molecular and morphological phylogeny of Menispermaceae (Ranunculales). Plant Systematics and Evolution 274:83-97.

JACQUES, F.M.B. \& DE FRANCESCHI, D. 2007. Menispermaceae wood anatomy and cambial variants. IAWA Journal 28:139-172.

JOSHI, A.C. 1937. Some salient points in the evolution of the secondary vascular cylinder of Amarantaceae and Chenopodiaceae. American Journal of Botany 24:3-9.

MAHEU, M.J. 1902. Recherches anatomiques sur les Ménispermacées. Journal de Botanique 16:365-378.

MENEZES, N.L., SILVA, D.C., ARRUDA, R.C.O., MELODE-PINNA, G.F., CARDOSO, V.A., CASTRO, N.M., SCATENA, V.L. \& SCREMIN-DIAS, E. 2005. Meristematic activity of the endodermis and the pericycle in the primary thickening in monocotyledons. Considerations on the "PTM". Anais da Academia Brasileira de Ciências 77:259-274.

MENNEGA, A.M.W. 1982. Stem structure of the New World Menispermaceae. Journal of the Arnold Arboretum 63:145-171.

METCALFE, C.R. \& CHALK, L. 1950. Anatomy of the dicotyledons: leaves, stem and wood in relation to taxonomy with notes on economic uses. Clarendon Press, Oxford, v.1.

MIKESELL, J.E. 1979. Anomalous secondary thickening in Phytolacca americana L. (Phytoloccaceae). American Journal of Botany 66:997-1005.

MIKESELL, J.E. \& POPHAM, C.H. 1976. Ontogeny and correlative relationship of the primary thickening meristem in four-o'clock plants (Nyctaginaceae) maintained under long and short photoperiods. American Journal of Botany 63:427-437.

NAIR, M.N.B. \& RAM, H.Y.M. 1990. Structure of wood and cambial variant in the stem of Dalbergia paniculata Roxb. IAWA Bulletin 11:379-391. 
OBATON, M. 1960. Les lianes ligneuses à structure anormale des forêts denses d'Afrique occidentale. Annales des Sciences Naturelles Botanic (new series) 12:1-220.

O’BRIEN, T.P. \& MCCULLY, M.E. 1981. The study of plant structure. Principles an selected methods. Termarcarphi Pty Ltd., Melbourne.

ORTIZ, R.D.C., KELLOGG, E.A. \& VAN DER WERFF, H. 2007. Molecular phylogeny of the moonseed family (Menispermaceae): implications for morphological diversification. American Journal of Botany 94:14251438.

PFEIFFER, H. 1926. Das aborne dickenwachstum-Handbuch der Pflanzenanatomie. Band IX. Verlag von Gebrüder Borntraaeger, Berlin.

RAJPUT, K.S. \& RAO, K.S. 2003. Cambial variant and xylem structure in the stem of Cocculus hirsutus (Menispermaceae). IAWA Journal 24:411-420.

RAJPUT, K.S. \& RAO, K.S. 2008. Radial secondary growth and formation of successive cambia and their products in Ipomoea hederifolia L. (Convolvulaceae). Botanical Journal of the Linnean Society 158:30-40.
RUDALL, P. 1991. Lateral meristem and stem thickening growth in monocotyledons. Botanical Review 57:150163.

SCHENCK, H. 1892. Beiträge zur Biologie und Anatomie der Lianen. I. Beiträge zur Biologie der Lianen. In Botanische Mittheilungen aus den Tropen, A.F.W. Schimper, ed., Gustav Fischer, Jena, v.4, p.1-253.

SOLEREDER, H. 1908. Systematic anatomy of Dicotyledons. Clarendon, Oxford.

STEVENSON, D.W. \& POPHAM, R.A. 1973. Ontogeny of the primary thickening meristem in seedlings of Bougainvillea spectabilis. American Journal of Botany 60:1-9.

VELLOSO, H.P., RANGEL-FILHO, A.L.R \& LIMA J.C.A. 1991. Classificação da vegetação brasileira, adaptada a um sistema universal. IBGE, Rio de Janeiro.

WHEAT, D. 1977. Successive cambia in the stem of Phytolacca dioica. American Journal of Botany 64:1209-1217.

YARROW, G.L. \& POPHAM, R.A. 1981. The ontogeny of the primary thickening meristem of Atriplex hortensis L. (Chenopodiaceae). American Journal of Botany 68:1042-1049. 